\title{
THE CONSTRUCTION OF A NORMATIVE INSTRUMENT FOR MEASURING ORGANISATIONAL CITIZENSHIP
}

\author{
E JOUBERT \\ A CRAFFORD \\ J M SCHEPERS \\ Programme in Industrial Psychology \\ Department of Human Resources Management \\ Rand Afrikaans University
}

\begin{abstract}
The aim of the study was to construct a normative instrument for measuring organisational citizenship. Based on studies done on organisational citizenship, a framework for identifying the locus of organisational citizenship was developed, and a questionnaire based on this framework was constructed. A factor analysis of the items of the instrument yielded two factors. These factors were interpreted as situational and dispositional loci of organisational citizenship. The two scales were subjected to item analysis and yielded reliability coefficients of 0,946 and 0,908 respectively. The implications of the findings are discussed.
\end{abstract}

\section{OPSOMMING}

Die doel van die studie was om 'n normatiewe meetinstrument te konstrueer om organisasieburgerskap te meet. 'n Raamwerk, gefundeer op navorsing oor organisasieburgerskap, is ontwerp en 'n vraelys gebaseer op dié raamwerk is gekonstrueer. 'n Faktorontleding van die items van die skaal het twee faktore opgelewer. Hierdie faktore is as situasionele en disposisionele lokusse van organisasieburgerskap geinterpreteer. Die skale is vervolgens aan itemontleding onderwerp en het betroubaarhede van 0,946 en 0,908, onderskeidelik, opgelewer. Die implikasies van die bevindinge word bespreek.

Twenty societal trends have been identified that will influence organisations and careers in the future (Graham, 1995). Amongst these are a tendency for company loyalty to be replaced by increasing self-absorption and cynicism. Corporate goals and individual goals will become unrelated and a diverging mixture of optimism and pessimism will spread as the realisation develops that a career for life is no longer the only option for both organisations and employees alike. Ultimately, leadership will disappear (Clarke, 1992).

At the same time that this divergence between the ideals of the individual and those of the organisation is occurring, organisations are in stern competition with one another. This competition is taking place in an arena where all of the competitors have equal access to a large variety of resources such as telecommunications, machinery, and raw materials - and where virtually the only factor restricting an organisation's access to these resources, is their financial might. In such an environment, differentiating one's organisation from the competition - when financial might is still being built - is possible only through proper and effective application of the one resource that not all organisations have equal access to - the human resource, and, more importantly, the advantages embedded in the quality, commitment, and loyalty of this resource, which managers need to unearth and nurture. In this arena, organisational strength and differentiation from the competition is possible only through employees' strong unity within the organisation, and their unwavering identification with its values, culture, and goals.

Norman Adami, managing director of South African Breweries Limited, when asked what has made the difference at $S A B$, said that every brewery has access to the best ingredients, the best equipment, and the world's leading technology - but it is the way these various elements are harnessed through people that forms a winning combination (Adami, 2000). Throughout organisations, a call will be made for a renewed focus on the human resources of these organisations, and how they can best be mobilised to offer and deliver services that will help differentiate one organisation from the next. Differentiation

Requests for copies should be addressed to: A Crafford, Department of Human Resource Management, RAU, PO Box 524, Auckland Park, 2006 such as this will have to be effected by a team of loyal and dedicated staff - staff who are willing to perform beyond the borders of their job descriptions and who identify with, and are committed to the corporation for which they work. This is the ideal that organisations and their staff ought to strive for.

However, the true picture is, to a large extent, in contrast with this. The schism developing between the goals of employees and those of the corporations for which they work is steadily widening. On the one hand, these competing organisations openly publicise and market the excellent service delivery customers can expect from their dedicated staff, whilst on the other hand these same staff members are losing their identity within their organisations and are becoming more and more alienated from the organisations' spirit and culture. In organisations where employees are lost to their corporations, the loss of their allegiance soon follows. Corporate successes will ultimately depend on the allegiance of an organisation's employees - not as scripted in television advertisements, but as genuinely exhibited and experienced by the customer on a dayto-day basis. Currently, what is really occurring to a large extent, is what Welch (2001) termed superficial congeniality - a picture that is pleasant on the surface, but far from it underneath.

In the face of this fundamental shift in work ethic, much organisational research has been focused on a form of employee behaviour that is not prescribed as part of his/her formal job role. Barnard (1938) first observed the phenomenon of organisational citizenship behaviour. He termed it extra-role behaviour.

Organisational citizenship behaviour, as labelled by Organ $(1977,1988)$ is now once again in the spotlight as the world of work undergoes this radical transformation that is threatening organisational futures.

\section{Organisational citizenship}

Organisational citizenship behaviour refers to a variety of theoretical constructs, including pro-social organisational behaviours (Brief \& Motowidlo, 1986), and extra-role behaviours (Graham, 1991; Katz \& Kahn, 1976, 1978; Van Dyne, Cummins, \& Mc Lean Parks, 1995). Smith, Organ, and Near (1983), and Organ and Konovsky (1989) drew attention to these 
behaviours, which largely went undetected or unrewarded within formal performance evaluation systems yet promoted the effective functioning of the organisation. Organ (1988) identified five broad groups of citizenship behaviour, viz. altruism, conscientiousness, civic virtue, sportmanship, courtesy and co-operation. Later studies added obedience, loyalty, and active participation in the organisation's governance, to the list (Graham, 1989; Organ, 1988; Van Dyne, Graham \& Dienesch, 1994).

In a study of organisational citizenship in South Africa, by Porteous and Sutherland (1997), the categories of behaviour constituting organisational citizenship behaviour (their study generated), differed somewhat from those of the American studies. The following top behaviours were generated through their research: exceeding job requirements, having a positive attitude, being pro-active, taking the lead, having respect for others, being trustworthy and discrete, being honest about everything, being innovative, being proud of your organisation, being ethical, frank, and direct, and volounteering to help others.

Studies focusing on the implications that organisational citizenship behaviour holds for the workplace, illustrate that there is a distinct relationship between these behaviours and positive organisational consequences (Podsakoff, Ahearne, \& MacKenzie, 1997). Evidence further indicates that organisations that have employees who exhibit organisational citizenship behaviours, outperform those that do not (Podsakoff \& MacKenzie, 1994). Buchanan (1974), found that employees who are citizens of their corporations are truly attached to the organisation to the extent that they are committed to, identify with, and enjoy membership in the organisation. Employees who are citizens, work harder than is expected, and are more productive in their jobs than employees with weaker citizenship attributes (Bashaw \& Grant, 1994). Clearly, in the current competitive climate, organisations need employees who will do those things that are not in any job description. Acts demonstrating organisational citizenship permeate the company's products and the services it delivers, and therefore directly impacts on organisational competitiveness.

Similar to the concept of organisational citizenship, though perhaps more widely known, is organisational commitment. For clarity a brief description of organisational commitment will be provided and a distinction between the two concepts will be drawn.

\section{Organisational commitment}

A common view of organisational commitment is one in which commitment is seen as attachment to an organisation to such an extent that the employees identify with, and are involved in it (Buchannan, 1974). Mowday, Porter and Steers (1982) define commitment as the relative strength of an individual's identification with and involvement in an organisation. This includes identification with the values and the goals of an organisation, a willingness to exert effort on behalf of the organisation, and a desire to be a member of the organisation. Organisational commitment is an employee's expression of his dedication and loyalty to an organisation, and is related to performance requirements (Bashaw \& Grant, 1994; Nicholson, 1995). Due to the relation between organisational commitment and performance requirements, it follows that organisational commitment behaviours are behaviours in accordance with formal role descriptions, and are behaviours that can reasonably be expected from an employee, and can thus be enforced by the employer (Katz \& Kahn, 1976, 1978).

Whilst there may not be unanimous agreement over the best way of defining and distinguishing between organisational commitment and organisational citizenship, there is certainly agreement that these behaviours exist and that they are distinct from one another.

\section{Differentiating between the two behaviours}

For the purposes of this study, it is proposed that one way of differentiating between the two constructs is to focus on the enforceability of the behaviour. It is proposed that organisational commitment behaviours are primarily in-role and can reasonably be enforced by the employer whereas organisational citizenship behaviour is primarily extra-role and tends to be far less enforceable by the employer. An employer cannot easily punish an employee for not exhibiting organisational citizenship behaviour.

However, punishment for not displaying organisational citizenship behaviour can still be meted out to an individual not by a position in authority, but by his peers, for example, through a loss of status, esteem, and respect. Punishment can also be meted out by the respondent to himself, dispositionally, through feelings, for example, of guilt, depression, anxiety, and cognitive dissonance.

Since organisational citizenship behaviour is a progression from organisational commitment behaviour, a definition of organisational citizenship behaviour would naturally include those behaviours exhibited by organisationally committed employees (Organ, 1988). In other words, citizenship of an organisation implies that there is commitment to the same. But this relationship does not flow the other way around commitment to an organisation does not necessarily mean that there is citizenship of the same.

Table1 illustrates the difference between organisational commitment and organisational citizenship - a citizen of an organisation behaves in a manner that exceeds what is expected from a committed employee.

TABLE 1

COMPARING ORGANISATIONAL COMMITMENT WITH ORGANISATIONAL CITIZENSHIP

\begin{tabular}{|c|c|}
\hline Organisational Commitment & Organisational Citizenship \\
\hline $\begin{array}{l}\text { Arriving on time and not leaving } \\
\text { early }\end{array}$ & Arriving earlier and leaving later \\
\hline Operating machinery correctly & $\begin{array}{l}\text { Operating machinery efficiently \& } \\
\text { productively }\end{array}$ \\
\hline Meeting management's expectations & Exceeding management's expectations \\
\hline Being honest at the workplace & $\begin{array}{l}\text { Encouraging honesty and reporting } \\
\text { dishonesty }\end{array}$ \\
\hline $\begin{array}{l}\text { Not bringing the company into } \\
\text { disrepute }\end{array}$ & Actively promoting the company \\
\hline
\end{tabular}

If employers assume that organisational citizenship behaviours contribute positively to the organisation, it is imperative that they are able to identify, firstly, which of their employees are likely to display these behaviours - which have a profoundly positive impact on organisational effectiveness - and secondly, why these employees are motivated to behave in this manner.

The motivators of organisational citizenship behaviour Few studies have been done on the actual motives for organisational citizenship behaviour (Barbuto, Brown, Wilhite \& Wheeler, 2001), and appeals have been made for more attention to be paid to the motivating factors that could help in predicting such behaviour (Organ, 1977).

There are various explanations of what motivates organisational citizenship. Prominent research undertaken by McClelland and his peers (McClelland, 1961; McClelland \& Boyatzis, 1982; McClelland \& Burnham, 1976) found that, like most forms of behaviour, organisational citizenship behaviour emerges from a motive; in other words, these behaviours are 
exhibited with a purpose, rather than solely altruistically. It is also believed that organisational citizenship behaviour is motivated by more than one source and that there is no single cause for such behaviour. A multi-source approach prevents the search for determinants of organisational citizenship behaviour from becoming too narrow and limited in scope. As such, the framework generated by this study gives an indication only of the extent to which the elements measured motivate organisational citizenship behaviour, and does not pretend to include the entirety of what motivates organisational citizenship behaviour.

Barbuto and Scholl (1998) offer a variable for predicting organisational citizenship behaviour. The sources of motivation identified by them include intrinsic and instrumental processes. Intrinsic motivation means that the person is motivated to perform a task for the sheer fun of it; the act itself is the reward, not the outcome (Barbuto \& Scholl, 1998). Instrumental processes are when rewards motivate individuals; an employee is motivated when the perception exists that a specific behaviour will lead to certain outcomes. An instrumental source of motivation can also exist when rewards are not tangible. For example an individual may behave in a way that satisfies reference group members in order to gain acceptance (Barbuto $\&$ Scholl, 1998).

The purpose of this study is to discern what some of the motivators of organisational citizenship behaviour might be and where these motivators are located. As a means of achieving this, the basic tenets of the environmental or learning theories of behaviourism and attribution theory have been drawn upon. Through the application of these theories, categories or groups of behaviour have been identified which may account for an employee's citizenship behaviours. Thereafter, the development of an instrument that measures the strengths of these motivators will be undertaken.

\section{Behaviourism}

Behaviourism emphasises the study of the environment in affecting behaviour. Behaviourists believe that human behaviour is geared towards claiming a reward and avoiding punishment (Munn, 1961; Papalia \& Olds, 1988). Behaviorists believe that people learn to be the kind of people they are and that behaviour can be divided into different kinds of activities that are either carried out or not, depending on what rewards or punishment have been received in the past for that behaviour, and what consequences can be expected in the future. Behaviourists believe that a person tends to behave in a certain manner in order to secure a specific outcome; the behaviour is geared towards earning a desired reward - hence reward is the motivator. A person who tends to act in a certain manner in order to avoid any negative consequences, has his behaviour geared towards avoiding this undesirable consequence - hence avoiding punishment is the motivator.

Further studies in the field of social psychology have revealed that people tend to conform to desired norms for two primary reasons - firstly because of a desire to be right, and, secondly because of the desire to be liked (Baron \& Byrne, 1991). In fulfilling these desires in a social context, punishment can be avoided and rewards can be secured. According to behaviourist theory, behaviour, in a social environment is observed and then copied. If rewarded, the learnt behaviour is repeated (Munn, 1961; Papalia \& Olds, 1988). If positive feedback is not experienced, this behaviour eventually ceases., or is unlearnt.

\section{Attribution theory}

Attribution theory suggests that there are situational as well as dispositional motives for behaviour (Heider, 1944, 1958). If certain behaviour is in congruence with one's character, beliefs, and self-concept, such behaviour is driven by one's disposition. If a one tends to behave in a certain manner because of the environment in which one is placed, such behaviour is driven primarily by the situation.

For the purposes of the development of the Locus of Organisational Citizenship Inventory (LOCI), the behaviourists' views of human behaviour as being motivated by reward or punishment, in conjunction with the principles of attribution theory, which view human behaviour as being either situationally or dispositionally located, were used as basis.

The environmental or learning views of human behaviour have been presented as the theoretical basis for the development of a framework for identifying the locus of organisational citizenship. The application of the theory to the framework will now be discussed.

\section{A framework for identifying the locus of organisational citizenship}

The broad principles of environmental or learning theories, though not generally lauded by $21^{\text {st }}$ century practitioners of psychology are, to a fairly large degree, applied by many human resources departments in the modern corporation. The principal tenets of these theories are made evident through practices such as performance management, reward schemes, incentive schemes, profit-sharing, status-based benefits (parking spaces, office size and location) and so on, all of which are "up for grabs", or can be "won" by the employee. The premise behind this management technique is, firstly, that all employees desire rewards and status, and, secondly, that these employees are motivated by the organisation's promise that such rewards or status will accrue to them if they exhibit desirable behaviours in the workplace.

Based on the theoretical premises of the theories presented above, a framework for identifying the locus of organisational citizenship was developed and a normative instrument constructed, based on this framework. The framework aims to show how the constructs of Rewardseeking, Punishment-avoidance, Dispositional Locus, and Situational Locus interact with one another in effecting organisational citizenship behaviour.

\section{METHOD}

\section{Sample}

The sample consisted of students, all of whom were enrolled in tertiary institutions. The respondents, therefore, had all successfully achieved at least a matric level educational qualification. The LOCI was administered to $\mathrm{N}=151$ persons. The sample's home languages were primarily African vernacular languages $(\mathrm{N}=87)$. The sample also included 14 Afrikaansspeaking persons and 42 English-speaking persons. The information on home languages was missing in respect of 5,3\% of the sample. Since the respondents were drawn from a population whose minimum educational level was matric, the use of English questionnaires was seen as justifiable.

The gender distribution showed a strong bias towards females $(71,5 \%)$ in contrast with males $(28,5 \%)$. The ages of the subjects showed a trend towards younger people $(82,1 \%$ were younger than 40 years of age).

\section{Measuring instruments}

The Locus of Control Inventory (LCI)

The locus of control construct of Rotter is based on social learning theory, and states that a person's expectancy about the outcomes of his/her actions is the major determinant of his/her behaviour (Rotter, 1954). A person with an internal locus of control perceives events to be contingent upon his own behaviour. However, a person with an external locus of control perceives events to be under the control of other unpredictable 
forces surrounding him, rather than upon his own actions (Rotter, 1966; Lefcourt, 1981).

Gore and Rotter (1963) found that persons with an internal locus of control are more inclined to act according to their convictions in any social circumstance than those with an external locus. Persons with an internal locus of control also exhibit stronger relationships between the attitudes they hold about an object and their overt behaviour in relation to that object. Persons with an external locus of control tend to be more susceptible to the effects of group and other normative or situational pressures. As such, a person with an external locus of control will be inclined to give a response that is heavily influenced by social pressure.

As a measure of locus of control, the Locus of Control Inventory (LCI) of Schepers was used. The LCI was developed by Schepers (1994) and is founded on attribution theory. It consists of three normative (as against ipsative) scales, viz. Internal Locus of Control, External Locus of Control, and Autonomy. A revised edition (1999) of the LCI was applied to 2091 first-year university students at the Rand Afrikaans University. The reliability of the three scales was established with the aid of Cronbach's coefficient alpha to be 0,$822 ; 0,871$ and 0,884 respectively.

The rationale for measuring locus of control in parallel with organisational citizenship was to determine if a correlation exists between a person's locus of control and his/her locus of organisational citizenship behaviour. For the purposes of this study it is postulated that statistically significant correlations exist.

\section{The Locus of Organisational Citizenship Inventory (LOCI)}

Based on the classifications of Porteous and Sutherland (1997), the Locus of Organisational Citizenship Inventory (LOCI) was developed with the purpose of identifying where an individual's locus of organisational citizenship behaviour lies, as well as to determine what motivates such behaviour. The instrument consists of 100 items specifically formulated to measure selected dimensions of organisational citizenship as identified by Porteous and Sutherland (1997) and Organ (1988) viz. altruism, conscientiousness, civic virtue, sportmanship, and courtesy and co-operation. The items were reviewed on an item by item basis and those items which seemed unclear or to have been repeated, were removed from the inventory (Bluen \& Donald, 1991; Rahim, 1983; Tittle, 1982).

Scoring is on a 7-point scale. The respondent indicates the degree to which he identifies with each item by marking the appropriate block on the answer sheet. Items were randomised across the questionnaire to avoid any response set according to the dimensions involved (Rahim, 1983).
The construct validity of the LOCI was evaluated factor analytically, as well as by examining its correlations with locus of control. Construct validity can be established through relationships with variables associated with the construct under consideration (Campbell \& Fiske, 1959; Mowday, Steers and Porter, 1979).

One ought to note that the constructs measured by the LOCI interact with, and influence one another. All of them have an influence, although to different degrees, on organisational citizenship behaviour. The LOCI allows one to discern where an individual's locus of organisational citizenship is most likely to lie (situational or dispositional locus), as well as what is most likely to motivate such behaviour (reward or punishment).

\section{Procedure}

With the assistance of one of the researcher's study leaders and the department of Human Resources Management at the Rand Afrikaans University, questionnaires were distributed to groups of available respondents at two tertiary institutions. Test groups varied from 15 to 60 respondents at a time. Participation in the study, and the inclusion of their names, was voluntary.

\section{Statistical analysis}

The LCI of Schepers is already fully developed, but for the purposes of this study, the reliabilities in respect of the sample used, were re-calculated. Using the existing scoring key of the LCI, the alpha coefficients were obtained for the three constructs, namely Internal Locus of Control, External Locus of Control, and Autonomy. All three proved to be acceptable.

One hundred items were written in respect of the LOCI, based on a-priori theoretical grounds, using the broad principles of environmental/learning theory. The items were intercorrelated with one another and subjected to a factor analysis merely with a view to sorting the items into clusters. Ultimately, eight meaningful clusters were obtained. These eight clusters were then used to compute eight subscores. The subscores were intercorrelated with one another. The intercorrelation matrix is given in Table 2 .

The eigenvalues of this intercorrelation matrix $(8 \times 8)$ were calculated and are given below in Table 3. Through an inspection of Table 3 one can see that there are two eigenvalues greater than unity.

According to Kaiser's (1961) criterion, this would suggest that there are two factors. Thus, two factors were extracted by means of a principal factor analysis. The obtained factors were rotated to simple structure using a Direct Oblimin rotation Factor I is well determined and can be identified as Situational

TABLE 2

MATRIX OF INTERCORRELATIONS OF THE SUBTESTS OF THE LOCI

\begin{tabular}{|c|c|c|c|c|c|c|c|c|}
\hline Subtest & Subtest 1 & Subtest 2 & Subtest 3 & Subtest 4 & Subtest 5 & Subtest 6 & Subtest 7 & Subtest 8 \\
\hline 1 & 1,000 & 0,062 & $-0,023$ & 0,651 & $-0,204$ & 0,487 & 0,532 & $-0,084$ \\
\hline 2 & 0,062 & 1,000 & 0,555 & $-0,041$ & 0,163 & 0,255 & $-0,038$ & 0,394 \\
\hline 3 & $-0,023$ & 0,555 & 1,000 & $-0,071$ & 0,336 & 0,161 & 0,000 & 0,383 \\
\hline 4 & 0,651 & $-0,041$ & $-0,071$ & 1,000 & $-0,162$ & 0,322 & 0,469 & $-0,096$ \\
\hline 5 & $-0,204$ & 0,163 & 0,336 & $-0,162$ & 1,000 & $-0,022$ & $-0,174$ & 0,146 \\
\hline 6 & 0,487 & 0,255 & 0,161 & 0,322 & $-0,022$ & 1,000 & 0,354 & 0,079 \\
\hline 7 & 0,532 & $-0,038$ & 0,000 & 0,469 & $-0,174$ & 0,354 & 1,000 & $-0,104$ \\
\hline 8 & $-0,084$ & 0,394 & 0,383 & $-0,096$ & 0,146 & 0,079 & $-0,104$ & 1,000 \\
\hline
\end{tabular}


Locus. Factor II is also well determined, and can be interpreted as Dispositional Locus. The rotated factor matrix is given in Table 4 .

TABLE 3

EIGENVALUES OF UNREDUCED INTERCORRELATION MATRIX OF LOCI BATTERY

\begin{tabular}{lccc}
\hline Root & Eigenvalue & \% of variance & Cumulative \% \\
\hline 1 & 2,504 & 31,295 & 31,295 \\
2 & 2,098 & 26,230 & 57,525 \\
3 & 0,874 & 10,927 & 68,452 \\
4 & 0,667 & 8,332 & 76,784 \\
5 & 0,602 & 7,523 & 84,307 \\
6 & 0,561 & 7,012 & 91,319 \\
7 & 0,386 & 4,828 & 96,147 \\
8 & 0,308 & 3,853 & 100,000 \\
Trace & 8,000 & & \\
\hline
\end{tabular}

\section{TABLE 4}

ROTATED FACTOR MATRIX OF LOCI (DIRECT OBLIMIN ROTATION)

\begin{tabular}{|c|c|c|c|c|c|}
\hline Variables & Items & K & Factor I & Factor II & $\mathbf{h}_{\mathrm{j}}^{2}$ \\
\hline Subtest 1 & $\begin{array}{l}73,81,66,88,86,87, \\
90,78,92,93,82,75, \\
50,91,97,54,62,60, \\
99,56,76,51,44,14, \\
98,70,100,69,45,26, \\
52,84,28,2,46,25\end{array}$ & 36 & 0,888 & $-0,030$ & 0,793 \\
\hline Subtest 2 & $\begin{array}{l}72,80,74,79,77,65 \\
31,94,85,96,33,64 \\
49,61,67,42,27,30\end{array}$ & 18 & 0,137 & 0,728 & 0,535 \\
\hline Subtest 3 & $\begin{array}{l}29,48,58,83,7,13 \\
16,5,47,95,38,55,9 \\
89,68,8,20,43,12\end{array}$ & 19 & 0,064 & 0,779 & 0,604 \\
\hline Subtest 4 & $\begin{array}{l}21,10,18,53,57,19 \\
17,59,23\end{array}$ & 9 & 0,698 & $-0,114$ & 0,512 \\
\hline Subtest 5 & $15,32,1,22,63$ & 5 & $-0,183$ & 0,333 & 0,153 \\
\hline Subtest 6 & $39,37,41,71,36$ & 5 & 0,564 & 0,245 & 0,358 \\
\hline Subtest 7 & $3,6,34,4$ & 4 & 0,626 & $-0,072$ & 0,404 \\
\hline Subtest 8 & $24,35,40,11$ & 4 & $-0,036$ & 0,510 & 0,264 \\
\hline \multicolumn{2}{|c|}{ Number of items per factor } & 100 & 54 & 46 & \\
\hline
\end{tabular}

FACTOR CORRELATION MATRIX

\begin{tabular}{lcc}
\hline Factor & Factor I & Factor II \\
\hline I & 1,000 & $-0,073$ \\
II & $-0,073$ & 1,000 \\
\hline
\end{tabular}

Accordingly two scales were formed corresponding to the two factors. These two scales were then subjected to item analysis using the NP50 program: Scale I, consisting of 54 items, has a reliability coefficient of 0,946 , and can be identified as Situational Locus. The item statistics in respect of this scale are given in Table 5.
TABLE 5

ITEM STATISTICS IN RESPECT OF SCALE I OF THE LOCI (SITUATIONAL LOCUS)

\begin{tabular}{|c|c|c|c|c|c|}
\hline Item & $\mathrm{N}$ & $\bar{X}_{g}$ & $S_{g}$ & $\mathbf{r}_{\mathrm{gx}} \mathbf{S}_{\mathrm{g}}$ & $r_{g x}$ \\
\hline 2 & 151 & 2,351 & 1,678 & 0,767 & 0,457 \\
\hline 3 & 151 & 2,854 & 1,481 & 0,561 & 0,379 \\
\hline 4 & 151 & 2,762 & 1,692 & 0,660 & 0,390 \\
\hline 6 & 151 & 2,960 & 1,478 & 0,721 & 0,488 \\
\hline 10 & 151 & 2,735 & 1,672 & 0,897 & 0,536 \\
\hline 14 & 151 & 3,212 & 1,560 & 0,856 & 0,549 \\
\hline 17 & 151 & 1,543 & 1,305 & 0,183 & 0,140 \\
\hline 18 & 151 & 2,596 & 1,994 & 1,033 & 0,518 \\
\hline 19 & 151 & 3,146 & 1,930 & 0,882 & 0,457 \\
\hline 21 & 151 & 2,616 & 1,693 & 0,937 & 0,554 \\
\hline 23 & 151 & 3,490 & 1,796 & 0,924 & 0,515 \\
\hline 25 & 151 & 3,205 & 1,726 & 0,746 & 0,433 \\
\hline 26 & 151 & 2,815 & 1,787 & 1,054 & 0,590 \\
\hline 28 & 151 & 3,543 & 2,106 & 0,967 & 0,459 \\
\hline 34 & 151 & 3,358 & 1,737 & 0,955 & 0,550 \\
\hline 36 & 151 & 5,947 & 1,599 & 0,288 & 0,180 \\
\hline 37 & 151 & 3,656 & 1,625 & 0,765 & 0,471 \\
\hline 39 & 151 & 3,980 & 1,981 & 0,812 & 0,140 \\
\hline 41 & 151 & 3,788 & 1,684 & 0,813 & 0,483 \\
\hline 44 & 151 & 2,311 & 1,328 & 0,662 & 0,499 \\
\hline 45 & 151 & 2,901 & 1,648 & 0,881 & 0,535 \\
\hline 46 & 151 & 3,351 & 1,658 & 0,692 & 0,418 \\
\hline 50 & 151 & 3,199 & 1,744 & 1,073 & 0,615 \\
\hline 51 & 151 & 2,411 & 1,597 & 0,956 & 0,599 \\
\hline 52 & 151 & 4,146 & 1,783 & 0,628 & 0,353 \\
\hline 53 & 151 & 2,159 & 1,515 & 0,921 & 0,608 \\
\hline 54 & 151 & 2,126 & 1,207 & 0,761 & 0,630 \\
\hline 56 & 151 & 3,053 & 1,680 & 0,954 & 0,568 \\
\hline 57 & 151 & 2,007 & 1,512 & 0,753 & 0,498 \\
\hline 59 & 151 & 2,344 & 1,653 & 0,821 & 0,497 \\
\hline 60 & 151 & 2,788 & 1,839 & 1,040 & 0,565 \\
\hline 62 & 151 & 3,199 & 1,890 & 1,090 & 0,576 \\
\hline 66 & 151 & 3,026 & 1,558 & 1,070 & 0,687 \\
\hline 69 & 151 & 3,848 & 2,006 & 0,862 & 0,430 \\
\hline 70 & 151 & 2,854 & 1,572 & 0,845 & 0,538 \\
\hline 71 & 151 & 3,033 & 1,722 & 0,623 & 0,362 \\
\hline 73 & 151 & 3,139 & 1,693 & 1,005 & 0,594 \\
\hline 75 & 151 & 3,172 & 1,620 & 0,784 & 0,484 \\
\hline 76 & 151 & 2,881 & 1,604 & 0,810 & 0,505 \\
\hline 78 & 151 & 2,424 & 1,426 & 0,835 & 0,586 \\
\hline 81 & 151 & 2,947 & 1,496 & 1,070 & 0,715 \\
\hline 82 & 151 & 2,834 & 1,467 & 0,779 & 0,531 \\
\hline 84 & 151 & 4,993 & 1,937 & 0,758 & 0,391 \\
\hline 86 & 151 & 2,993 & 1,745 & 1,216 & 0,697 \\
\hline 87 & 151 & 2,722 & 1,634 & 0,988 & 0,605 \\
\hline 88 & 151 & 3,205 & 1,841 & 1,124 & 0,610 \\
\hline 90 & 151 & 2,841 & 1,592 & 0,939 & 0,590 \\
\hline 91 & 151 & 3,007 & 1,619 & 0,920 & 0,569 \\
\hline 92 & 151 & 3,450 & 1,836 & 1,015 & 0,553 \\
\hline 93 & 151 & 2,238 & 1,295 & 0,799 & 0,617 \\
\hline 97 & 151 & 3,113 & 1,639 & 0,865 & 0,528 \\
\hline 98 & 151 & 4,152 & 2,125 & 1,080 & 0,508 \\
\hline 99 & 151 & 2,563 & 1,639 & 0,998 & 0,609 \\
\hline 100 & 151 & 2,563 & 1,486 & 0,872 & 0,587 \\
\hline
\end{tabular}

MEANS AND STANDARD DEVIATIONS OF ITEM STATISTICS IN RESPECT OF SCALE I OF THE LOCI (SITUATIONAL LOCUS)

\begin{tabular}{lrrrrr}
\hline & $\mathbf{K}$ & $\overline{\mathbf{X}}_{\mathrm{g}}$ & $\boldsymbol{S}_{\mathrm{g}}$ & $\mathbf{r}_{\mathrm{gx}} \boldsymbol{S}_{\mathrm{g}}$ & $\mathbf{r}_{\mathrm{gx}}$ \\
\hline Mean & 54 & 3,047 & 1,669 & 0,858 & 0,515 \\
Standard deviation & 540,720 & 0,195 & 0,188 & 0,109 & \\
\hline
\end{tabular}


Scale II, consisting of 46 items, has a reliability coefficient of 0,908 and can be interpreted as Dispositional Locus. The item statistics in respect of this scale are given in Table 6.

TABLE 6

ITEM STATISTICS IN RESPECT OF SCALE II OF THE LOCI (DISPOSITIONAL LOCUS)

\begin{tabular}{|c|c|c|c|c|c|}
\hline Item & $\mathrm{N}$ & $\bar{X}_{g}$ & $S_{g}$ & $\mathbf{r}_{\mathrm{gx}} \mathbf{S}_{\mathrm{g}}$ & $\mathbf{r}_{g_{x}}$ \\
\hline 1 & 151 & 6,331 & 1,193 & 0,363 & 0,304 \\
\hline 5 & 151 & 6,232 & 0,852 & 0,426 & 0,500 \\
\hline 7 & 151 & 6,232 & 0,860 & 0,368 & 0,428 \\
\hline 8 & 151 & 6,252 & 1,302 & 0,651 & 0,500 \\
\hline 9 & 151 & 6,232 & 1,092 & 0,379 & 0,347 \\
\hline 11 & 151 & 6,146 & 1,378 & 0,700 & 0,508 \\
\hline 12 & 151 & 5,576 & 1,507 & 0,595 & 0,395 \\
\hline 13 & 151 & 6,272 & 0,916 & 0,507 & 0,553 \\
\hline 15 & 151 & 6,086 & 1,280 & 0,515 & 0,402 \\
\hline 16 & 151 & 6,391 & 0,832 & 0,436 & 0,523 \\
\hline 20 & 151 & 5,477 & 1,514 & 0,313 & 0,207 \\
\hline 22 & 151 & 5,755 & 1,428 & 0,530 & 0,371 \\
\hline 24 & 151 & 5,848 & 1,370 & 0,596 & 0,435 \\
\hline 27 & 151 & 6,258 & 1,235 & 0,574 & 0,465 \\
\hline 29 & 151 & 6,596 & 0,634 & 0,446 & 0,704 \\
\hline 30 & 151 & 5,205 & 1,638 & 0,397 & 0,242 \\
\hline 31 & 151 & 6,305 & 1,071 & 0,579 & 0,541 \\
\hline 32 & 151 & 6,086 & 1,083 & 0,426 & 0,394 \\
\hline 33 & 151 & 5,901 & 1,473 & 0,742 & 0,504 \\
\hline 35 & 151 & 4,457 & 1,739 & 0,182 & 0,105 \\
\hline 38 & 151 & 6,358 & 0,926 & 0,509 & 0,549 \\
\hline 40 & 151 & 6,000 & 1,238 & 0,668 & 0,540 \\
\hline 42 & 151 & 6,007 & 1,383 & 0,694 & 0,501 \\
\hline 43 & 151 & 6,066 & 1,118 & 0,492 & 0,440 \\
\hline 47 & 151 & 6,205 & 0,851 & 0,355 & 0,418 \\
\hline 48 & 151 & 6,424 & 0,875 & 0,469 & 0,536 \\
\hline 49 & 151 & 6,219 & 1,460 & 0,654 & 0,448 \\
\hline 55 & 151 & 6,318 & 1,002 & 0,605 & 0,603 \\
\hline 58 & 151 & 6,623 & 0,661 & 0,405 & 0,613 \\
\hline 61 & 151 & 6,086 & 1,286 & 0,529 & 0,412 \\
\hline 63 & 151 & 4,126 & 2,183 & 0,481 & 0,220 \\
\hline 64 & 151 & 6,093 & 1,489 & 0,679 & 0,456 \\
\hline 65 & 151 & 6,272 & 1,409 & 0,573 & 0,407 \\
\hline 67 & 151 & 5,887 & 1,647 & 0,739 & 0,449 \\
\hline 68 & 151 & 6,099 & 1,300 & 0,603 & 0,464 \\
\hline 72 & 151 & 6,073 & 1,447 & 0,930 & 0,643 \\
\hline 74 & 151 & 5,974 & 1,465 & 0,933 & 0,637 \\
\hline 77 & 151 & 5,742 & 1,393 & 0,691 & 0,496 \\
\hline 79 & 151 & 6,020 & 1,273 & 0,788 & 0,619 \\
\hline 80 & 151 & 6,318 & 1,180 & 0,752 & 0,637 \\
\hline 83 & 151 & 6,450 & 0,862 & 0,512 & 0,594 \\
\hline 85 & 151 & 5,702 & 1,603 & 0,863 & 0,538 \\
\hline 89 & 151 & 5,848 & 1,118 & 0,531 & 0,475 \\
\hline 94 & 151 & 6,377 & 1,094 & 0,706 & 0,646 \\
\hline 95 & 151 & 6,298 & 0,999 & 0,323 & 0,324 \\
\hline 96 & 151 & 6,503 & 1,070 & 0,572 & 0,535 \\
\hline
\end{tabular}

MEANS AND STANDARD DEVIATIONS OF ITEM STATISTICS IN RESPECT OF SCALE II OF THE LOCI (DISPOSITIONAL LOCUS)

\begin{tabular}{lrrrrr}
\hline & $\mathrm{K}$ & $\overline{\mathrm{X}}_{\mathrm{g}}$ & $\mathbf{S}_{\mathrm{g}}$ & $\mathbf{r}_{\mathrm{gx}} \mathbf{S}_{\mathrm{g}}$ & $\mathbf{r}_{\mathrm{gx}}$ \\
\hline Mean & 46 & 6,037 & 1,233 & 0,561 & 0,470 \\
Standard deviation & 46 & 0,474 & 0,306 & 0,164 & 0,126 \\
\hline
\end{tabular}

Cronbach alpha: 0,908
As far as content is concerned, the 100 items fall into four categories namely Reward-seeking, Punishmentavoidance, Dispositional Locus, and Situational Locus. Each of the categories consists of 25 items and were scored according to the theoretical rationale of the LOCI. Subscores were then computed in respect of each of the categories.

In the final analysis of the data the four subscores of the LOCI were also correlated with the various scores of the LCI and the two scores (Situational Locus and Dispositional Locus) of the LOCI. The intercorrelations are given in Table 7.

Table 7 shows that Scales I and II are essentially uncorrelated.

Scale I correlates positively with the two subscales identified as Situational, Avoidance of Punishment (SAP) and Seeking for Reward (SSR). Scale I also correlates positively with External Locus of Control. Scale I correlates, although not very highly, with the subscale identified as Avoidance of Punishment (DAP).

Scale II correlates positively with the two subscales identified as Dispositional, Avoidance of Punishment (DAP) and Seeking for Reward (DSR). Scale II also correlates positively with Internal Locus of Control, and Autonomy.

In order to determine whether there are natural groupings (homogeneous clusters) of subjects with respect to organisational citizenship, the sample was subjected to a cluster analysis. The two scores of the LOCI were used as input variables. The clustering program used is known as Clix (Muller, 1975). The program operates on the basis of an iterative reclassification of objects. The maximum number of clusters that is expected must be specified beforehand. Thereafter the program iteratively forms fewer and fewer clusters until an optimal number of clusters are arrived at. There is no statistical test for the optimal number of clusters. The researcher has to decide on the number of clusters to use through an inspection of the clusters obtained. In the current case, four clusters seemed to be optimal.

The means and standard deviations of the various clusters in respect of Situational Locus and Dispositional Locus as measured by the LOCI are given in Table 8 . It merits mentioning that the scores were standardised beforehand to have a mean of 50 and a standard deviation of 10 .

From an inspection of this table, it is clear that cluster one is average on Situational Locus but low on Dispositional Locus. By contrast, cluster three is low on Situational Locus and somewhat higher than average on Dispositional Locus. Cluster two is very high on Situational Locus and above average on Dispositional Locus. However, since this cluster is based on only eight cases, it might not be a very stable cluster. Cluster four is above average on both Situational Locus and Dispositional Locus.

In order to test whether there are meaningful differences between these four clusters in respect of the locus of control measures, the means of the four clusters were calculated in respect of Internal Locus of Control, External Locus of Control, and Autonomy. The means and standard deviations of the various clusters are given in Table 9.

The magnitude of the means of the various clusters in respect of the locus of control measures can be judged by referring to the means of the total sample. To illustrate, for example, the mean in respect of Internal Locus of Control for Cluster 1 is 156,13 compared with the total sample mean of 165,83 . It is clear that there is not a very large difference between the two means. In fact the means of all four of the clusters are not very different from the mean of the total sample. By contrast, if one looks at Autonomy, the means of Clusters 1 through 4 are 156,58; 183,13; 179,47 and 170,40 
TABLE 7

INTERCORRELATIONS OF LCI AND LOCI

\begin{tabular}{|c|c|c|c|c|c|c|c|c|c|}
\hline & & LCI & & & & & & LOCI & \\
\hline & & ording to key & & & scores of $t$ & LOCI scale & & Two s & f LOCI \\
\hline & Autonomy & External & Internal & SAP & SSR & DAP & DSR & Scale I & Scale II \\
\hline Autonomy & 1,000 & $-0,063$ & $0,638 * *$ & 0,019 & 0,017 & 0,194 * & $0,481 * *$ & 0,011 & 0,375 ** \\
\hline External & $-0,063$ & 1,000 & 0,135 & $0,525 * *$ & 0,534 * * & 0,124 & 0,150 & 0,560 ** & 0,087 \\
\hline Internal & 0,638 ** & 0,135 & 1,000 & 0,040 & 0,122 & 0,378 * * & $0,651 * *$ & 0,074 & 0,569 ** \\
\hline SAP & 0,019 & $0,525 * *$ & 0,040 & 1,000 & 0,787 * * & 0,130 & 0,039 & $0,949 *$ * & $-0,001$ \\
\hline SSR & 0,017 & 0,534 ** & 0,122 & 0,787 ** & 1,000 & 0,194 * & 0,067 & 0,932 * * & 0,055 \\
\hline DAP & 0,194 * & 0,124 & 0,378 * * & 0,130 & 0,194 * & 1,000 & 0,625 ** & 0,205 * & 0,883 ** \\
\hline DSR & $0,481 * *$ & 0,150 & $0,651 * *$ & 0,039 & 0,067 & $0,625 * *$ & 1,000 & 0,057 & 0,885 ** \\
\hline Scale I & 0,011 & 0,560 ** & 0,074 & 0,949 * * & 0,932 * * & 0,205 * & 0,057 & 1,000 & 0,037 \\
\hline Scale II & $0,375 * *$ & 0,087 & $0,569 * *$ & $-0,001$ & 0,055 & 0,883 ** & 0,885 * * & 0,037 & 1,000 \\
\hline
\end{tabular}

* Correlation is significant at the 0,05 level (2-tailed)

** Correlation is significant at the 0,01 level (2-tailed)

TABLE 8

MEANS AND STANDARD DEVIATIONS OF THE VARIOUS

CLUSTERS IN RESPECT OF SITUATIONAL LOCUS

AND DISPOSITIONAL LOCUS OF THE LOCI

\begin{tabular}{|c|c|c|c|c|c|c|c|}
\hline \multirow[b]{2}{*}{ CLUSTERS } & & & \multicolumn{2}{|c|}{ MEANS OF CLUSTERS } & \multicolumn{3}{|c|}{ STANDARD DEVIATIONS OF CLUSTERS } \\
\hline & & & SITUATIONAL & DISPOSITIONAL & SITUATIONAL & DISPOSITIONAL & $\mathrm{N}$ \\
\hline 1 & Ave & Low & 49,000 & 38,396 & 7,377 & 7,999 & 48 \\
\hline 2 & High & Ave $^{+}$ & 77,500 & 54,750 & 8,452 & 7,005 & 8 \\
\hline 3 & Low & $\mathrm{Ave}^{+}$ & 38,125 & 55,344 & 5,160 & 4,810 & 32 \\
\hline 4 & $\mathrm{Ave}^{+}$ & $\mathrm{Ave}^{+}$ & 52,794 & 55,571 & 3,638 & 5,120 & 63 \\
\hline TOTAL & 151 & & & & & & \\
\hline
\end{tabular}

Table 9

MEANS AND STANDARD DEVIATIONS OF THE VARIOUS CLUSTERS IN RESPECT OF INTERNAL LOCUS, EXTERNAL LOCUS AND AUTONOMY

\begin{tabular}{|c|c|c|c|c|c|c|c|c|c|c|}
\hline \multirow[b]{2}{*}{ Clusters } & \multicolumn{5}{|c|}{ MEANS OF THE CLUSTERS } & \multicolumn{5}{|c|}{ STANARD DEVIATIONS OF THE CLUSTERS } \\
\hline & 1 & 2 & 3 & 4 & Total & 1 & 2 & 3 & 4 & Total \\
\hline \multirow[t]{2}{*}{ Int. locus } & 156,12 & 171,25 & 170,75 & 170,04 & 165,83 & 17,360 & 7,573 & 10,30 & 11,272 & 14,69 \\
\hline & 5 & 0 & 0 & 4 & & 5 & 8 & 3 & 5 & \\
\hline \multirow[t]{2}{*}{ Ext. locus } & 81,271 & 107,75 & 72,844 & 94,206 & 86,285 & 23,463 & 22,09 & 19,86 & 20,721 & 23,49 \\
\hline & & 0 & & & & 6 & 6 & 9 & & 2 \\
\hline Autonomy & 156,58 & 183,12 & 179,46 & 170,39 & 168,60 & 23,565 & 14,22 & 17,67 & 14,831 & 20,56 \\
\hline y & 3 & 5 & 9 & 7 & 3 & & 7 & 8 & & 6 \\
\hline $\mathrm{N}$ & 48 & 8 & 32 & 63 & 151 & 48 & 8 & 32 & 63 & 151 \\
\hline
\end{tabular}

$\mathrm{F}(9,353,043)=8,904 ; \mathrm{p}=0,001$

respectively, compared with a total sample mean of 168,60 . One can see that the means of Clusters 2 and 3 are considerably greater than the mean of the total sample. The mean of Cluster 1 is considerably lower than the mean of the total sample. Finally when looking at the mean of Cluster 4, one sees that it does not differ significantly from the mean of the total sample.

In order to test whether the vectors of means of the four clusters differ statistically significantly from one another in respect of Internal Locus of Control, External Locus of Control, and Autonomy, a MANOVA was done. A statistically significant result was obtained. Wilks' Lambda was equal to 0,608 with an associated F-value $(9,353,043)=8,904 ; \mathrm{p}<0,001$. By virtue of the fact that the MANOVA was statistically highly significant, a series of one-way analyses of variance was conducted. It was found that all three ANOVA's were statistically significant. These findings are given in Table 10 .

Finally, in order to determine whether the group means of the various clusters differ significantly from one another, each of the clusters were paired with every other one using Scheffè's multiple comparisons technique. The results, given in Table 11, present the multiple comparisons of the means of the various clusters in respect of Internal Locus, External Locus and Autonomy. 
TABLE 10

ANOVA: COMAPRISON OF THE MEANS OF THE FOUR CLUSTERS IN RESPECT OF INTERNAL CONTROL, EXTERNAL CONTROL AND AUTONOMY

\begin{tabular}{lcccccc}
\hline Source & $\begin{array}{c}\text { Dependent } \\
\text { Variable }\end{array}$ & $\begin{array}{c}\text { Type III sum } \\
\text { of Squares }\end{array}$ & DF & Mean Square & F & p(F) \\
\hline Clusters & Internal & 6651,254 & $(3,147)$ & 2217,085 & 12,662 & 0,001 \\
External & 14627,240 & $(3,147)$ & 4875,747 & 10,517 & 0,001 & \\
Autonomy & 12602,569 & $(3,147)$ & 4200,856 & 12,146 & 0,001 & \\
\hline
\end{tabular}

Note: Wilks' Lambda $=0,608$

F-value $(9,353,043)=8,904 ; \mathrm{p}<0,001$

TABLE 11

SHEFFÈ'S MULTIPLE COMPARISONS: COMPARISON OF THE MEANS OF THE VARIOUS CLUSTERS IN RESPECT OF INTERNAL LOCUS, EXTERNAL LOCUS AND AUTONOMY

\begin{tabular}{lrrrrrr}
\hline & \multicolumn{7}{c}{ Pairs of clusters } \\
\hline & $1 / 2$ & $1 / 3$ & $1 / 4$ & $2 / 3$ & $2 / 4$ & $3 / 4$ \\
Internal locus & $0,033^{*}$ & $<0,001 *$ & $<0,001^{*}$ & 1,000 & 0,996 & 0,996 \\
External locus & $0,018^{*}$ & 0,404 & $0,023^{*}$ & $0,001 *$ & 0,425 & $<0,001^{*}$ \\
Autonomy & $0,004^{*}$ & $<0,001 *$ & $0,002^{*}$ & 0,969 & 0,348 & 0,173 \\
\hline
\end{tabular}

Note: * indicates statistically significant

From an inspection of Table 11 it is clear that in terms of Autonomy there are statistically significant differences between Clusters 1 and 2, between Clusters 1 and 3 and between Clusters 1 and 4. In terms of External Locus of Control, Clusters 1 and 2, Clusters 1 and 4, Clusters 2 and 3, and Clusters 3 and 4 differ from one another. In terms of Internal Locus of Control, statistically significant differences exist only between Clusters 1 and 2, Clusters 1 and 3, and Clusters 1 and 4 .

Table 12 further describes the clusters in terms of LCI and LOCI.

TABLE 12

DESCRIPTION OF CLUSTERS IN TERMS OF LCI AND LOCI

\begin{tabular}{lccccc}
\hline & \multicolumn{2}{c}{ LCI } & \multicolumn{3}{c}{ LOCI } \\
Cluster & Autonomy & External Locus & Internal Locus & Situational & Dispositional \\
\hline 1 & Low & Ave- & Low & Ave & Low \\
2 & High & High & High & High & Ave+ \\
3 & High & Low & High & Low & Ave $^{+}$ \\
4 & High & Ave + & Ave & Ave + & Ave $^{+}$ \\
\hline
\end{tabular}

In order to determine whether there are meaningful differences between the biographical variables in respect of the four clusters, Chi-squares were calculated in respect of gender, educational qualification, language, and age. The frequency distributions of the biographical variables of the various clusters are given in Table 13.

It turned out that only the chi-square in respect of educational qualification was statistically significant. The contingency table of educational qualification against clusters 1 to 4 is given in Table 14. Given in this table are the expected and observed counts. The expected counts are given in brackets.

TABLE 14

Contingency table: EDUCATIONAL QUaLification TABULATED AGAINST CLUSTERS

\begin{tabular}{llrrrr}
\hline Clusters & Std 10 & Graduate & Post Graduate & Total \\
\hline 1 & Count & 11 & 12 & 25 & 48 \\
& Expected Count & $(7,3)$ & $(15,6)$ & $(25,1)$ & \\
2 & Count & 0 & 0 & 8 & 8 \\
& Expected Count & $(1,2)$ & $(2,6)$ & $(4,2)$ & \\
3 & Count & 2 & 9 & 21 & 32 \\
& Expected Count & $(4,9)$ & $(10,4)$ & $(16,7)$ & \\
4 & Count & 10 & 28 & 25 & 63 \\
& Expected Count & $(9,6)$ & $(20,4)$ & $(33,0)$ & \\
\hline Total & Count & 23 & 49 & 79 & 151 \\
& Expected Count & 23 & 49 & 79 & \\
\hline
\end{tabular}

Note: $[\mathrm{X} 2=17,669(6) ; \mathrm{p}=0,007]$

When looking at the educational qualifications in respect of Cluster 4 , for example, it can be seen that 20 graduates were expected in that cluster. However, there were 28 graduates. Cluster 4, therefore, has a significantly higher number of graduates included in its numbers, than was expected. In terms of post-graduates in the same cluster, there were fewer than was expected, namely 25 as against an expected number of 33. In terms of Cluster 3, five matriculants were expected, yet there were only two.

\section{DISCUSSION}

The statistical analysis indicates that the LOCI, as an instrument, has acceptable metrical properties and that the motives and loci of organisational citizenship behaviour can, for the purposes of this study, be identified in terms of the four clusters that the items of the LOCI have been constructed to measure. It follows that, by applying the LOCI, one can determine where both the locus (i.e. internal versus external) of an individual's proneness to exhibit

TABLE 13

FREQUENCY DISTRIBUTIONS OF THE BIOGRAPHICAL VARIABLES IN RESPECT OF THE VARIOUS CLUSTERS

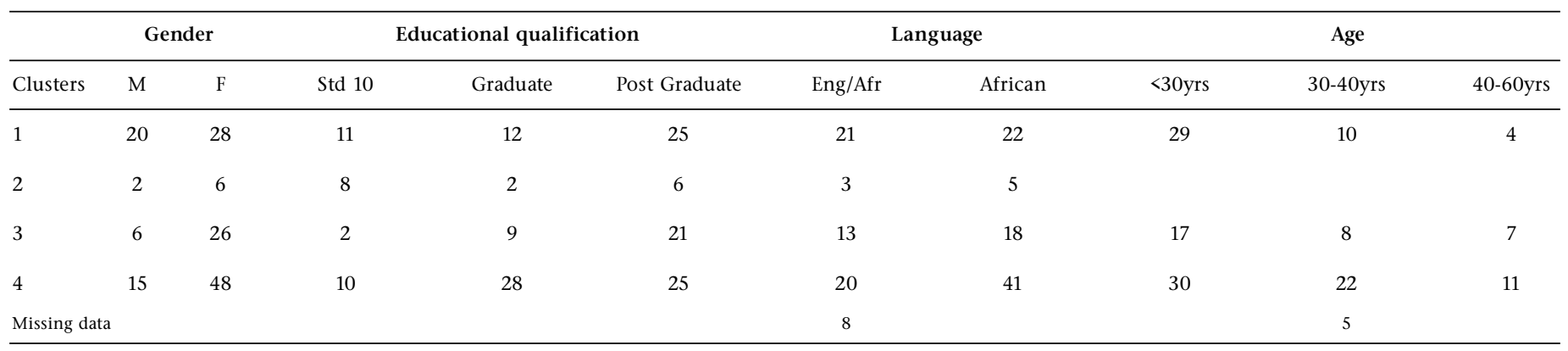


organisational citizenship behaviour lies, as well as what motivates (i.e. seeking reward versus avoiding punishment) such behaviours.

The interpretation of the results leads to the following conclusions:

Autonomy, as identified by the LCI, correlates significantly with Internal Locus of Control. It also correlates significantly with Scale II (Dispositional Locus of Organisational Citizenship Behaviour) and, the two dispositional subscores which correlate with Scale II, Avoiding Punishment and Seeking Reward. This suggests that a person who shows a great deal of autonomy, very likely has an internal locus of control, and his/her organisational citizenship behaviour tends to be governed by his/her disposition.

External Locus of Control, as identified by the LCI, correlates significantly with Scale I (Situational Locus of Organisational Citizenship Behaviour) and the two situational subscores, which correlate with Scale I, namely Avoiding Punishment and Seeking Reward. This suggests that a person who has an external locus of control is not likely to function autonomously, and his/her organisational citizenship behaviour is largely a function of the situation he/she interacts with.

Internal Locus of Control correlates with Scale II (Dispositional Locus of Organisational Citizenship Behaviour) and the two dispositional subscores, namely Avoiding Punishment and Seeking Reward. This suggests that a person who has an internal locus of control tends to exhibit autonomous behaviour and his/her organisational citizenship behaviour tends to be governed by his/ her disposition.

As a demonstration of the practical usefulness of this study, consider a scenario where two job applicants undergo a paper and pencil integrity test and both are found to have similar values on theft-proneness. On account of their similar scores, theft-proneness will not be a deciding factor when it comes to deciding on whom to hire.

By contrast, assume that the test could have provided the following information: Applicant A is not prone to thievery for fear of the negative situational consequences, such as punishment for stealing. And applicant B is not prone to thievery because he/she does not like the feelings of discomfort it evokes.

This is the sort of information that the application of the LOCI can provide - the loci and motives for the behaviour are now discernable and the employer can tell what an applicant's motives are for not being theft prone. This is important to know because in situations where social norms and social prescriptions are compromised, a person with a dispositional locus of organisational citizenship tends to act in a certain manner more consistently than the person who looks to the situation for cues.

Organisational citizenship is more than an extension of one's belief in moral principles from the privacy of one's home and family life. Organisational citizenship implies identification with, and belief in the principles, morals, and values of the organisation within which one works (whereas organisation commitment implies mere adherence to the same). Behaviour in line with the values and norms of the organisation is seen as "ethical", and "the right thing to do". Organisational citizenship serves as a guide for organisational performance, and through these behaviours, quality, social responsibility, and ethical behaviour can combine to produce profits.

Turning a mere committed employee into a genuine citizen, is possible through the adoption of the organisation's values, norms, and standards by the employee. However, his mere acceptance thereof is not sufficient. Only genuine identification therewith, will lead to organisational citizenship behaviour.

Transformation of its current corps of employees into genuine citizens is one option an organisation can adopt in gearing up to meet the challenges of the transforming workplace. The other option is to identify likely citizens at the recruitment stage, and then employ them. This, ultimately, is where the value of the LOCI lies.

\section{REFERENCES}

Adami, N. (2000). S.A. Breweries: Developing people makes good beer sense. Management Today, 28-29.

Barbuto, J.E. (jr), Brown, L.L., Wilhite, M.S. \& Wheeler, D.W. (2001). Testing the underlying motives of organisational citizenship behaviours: A field study of agricultural co-op workers. 28th Annual National Agricultural Education Research Conference. 28, 539-553.

Barbuto, J.E. \& Scholl, R.W. (1998). Motivation sources inventory: Development and validation of new scales to measure an integrative taxonomy of motivation. Psychological Reports, 82, 1011-1022.

Barnard, C.I. (1938). The functions of the executive. Cambridge, MA: Harvard University Press.

Baron, R.A. \& Byrne, D. (1991). Social Psychology. Needham Heights, MA: Allyn and Bacon.

Bashaw, E.R. \& Grant, S.E. (1994). Exploring the distinctive nature of work commitments: Their relationships with personal characteristics, job performance, and propensity to leave. Journal of Personal Selling and Sales Management, 14, 41-56.

Bluen, S.D. \& Donald, C.H.M. (1991). The nature and measurement of in-company industrial relations climate. South African Journal of Psychology, 21, 12-20.

Brief, A.P. \& Motowidlo, S.J. (1986). Prosocial organizational behaviours. Academy of Management Review, 10, 710-725.

Buchanan, B. (1974). Building organisational commitment: The socialisation of managers in work organisations. Administrative Science Quarterly, 19, 533-546.

Campbell, D.T. \& Fiske, D.W. (1959). Convergent and discriminant validation by the multitrait-multimethod matrix. Psychological Bulletin, 56, 81-105.

Clarke, F. A. (1992). Total career management: Strategies for creating management careers. Cambridge: McGraw-Hill.

Gore, P.M. \& Rotter, J.B. (1963). A personality correlate of social action. Journal of Personality, 31, 58-64.

Graham, J. (1989). Organisational citizenship behaviour: Construct redefinition, operationalisation, and validation. Unpublished manuscript, Loyola University, Chicago.

Graham, J. (1991). An essay on organisational citizenship behaviour. Employee Responsibilities and Rights Journal, 4, 249-270.

Graham, J.R. (1995). Twenty trends that will shape businesses and careers. HR Focus, 1, 9-10.

Heider, F. (1944). Social perception and phenomenal causality. Psychological Review, 51, 358-374.

Heider, F. (1958). The psychology of interpersonal relations. New York: Wiley.

Katz, R.L. \& Kahn, R.L. (1976, 1978). The social psychology of organisations. New York: Wiley.

Kaiser, H.F. (1961). A note on Guttman's lower bound for the number of common factors. British Journal for Statistical Psychology, 14 (1), 1.

Lefcourt, H.M. (1981). Research with the locus of control construct. New York: Academic Press.

McClelland, D.C. (1961). The achieving society. New York: Free Press.

McClelland, D.C. \& Boyatzis, R. (1982). The leadership motive pattern and long-term success in management. Journal of Applied Psychology, 67, 737-743. 
McClelland, D.C. \& Burnham, D. (1976). Power is the great motivator. Harvard Business Review, 25. (March-April): 159166.

Mowday, R.T. Porter, L.W. \& Steers, R.M. (1979). The measurement of organisational commitment. Journal of Vocational Behavior, 18, 224-247.

Mowday, R.T. Porter, L.W. \& Steers, R.M. (1982). EmployeeOrganization linkages: The Psychology of commitment, absenteeism, and turnover. New York: Academic Press.

Muller, M.W. (1975). A comparison of some clustering techniques. Johannesburg: University of the Witwatersrand (M.Sc Dissertation).

Munn, N. (1961). Psychology: The fundamentals of human adjustment (4th ed.). London: George G. Harrap \& Co. Ltd.

Nicholson, N. (1995). Blackwell encyclopaedic dictionary of organisational behaviour. Oxford: Blackwell

Organ, D.W. (1977). A reappraisal and reinterpretation of the satisfaction-causes-performance hypothesis. Academy of Management Review, 2, 46-53.

Organ, D.W. (1988). Organizational citizenship behavior: The good soldier syndrome. Lexington, M.A.: Lexington.

Organ, D.W. \& Konovsky, M. (1989). Cognitive versus affective determinants of organizational citizenship behavior. Journal of Applied Psychology, 74, 157-164.

Papalia, D.E. \& Olds, S.W. (1988). Psychology. New York: McGraw-Hill.

Podsakoff, P.M., Ahearne, M. \& MacKenzie, S.B. (1997). Organizational citizenship behavior and the quantity and quality of work group performance. Journal of Applied Psychology, 82, 262-270.

Podsakoff, P.M. \& MacKenzie, S.B. (1994). Organizational citizenship behavior and sales unit effectiveness. Journal of Marketing Research, August 1994, 351-363.
Porteous, E. \& Sutherland, M. (1997). Citizenship of an organisation. People Dynamics, June, 27-31.

Rahim, M.A. (1983). Measurement of organisational conflict. Journal of General Psychology, 109, 189-199.

Rotter, J.B. (1954). Social learning and clinical psychology. Englewood Cliffs, NJ: Prentice-Hall.

Rotter, J.B. (1966). Generalized expectancies for internal versus external control of reinforcement. Psychological Monographs, 80 (1), 609.

Schepers, J.M. (1995). Die Lokus van Beheer-vraelys: Konstruksie en evaluering van 'n nuwe meetinstrument. [Tegniese verslag] Randse Afrikaanse Universiteit, Johannesburg.

Schepers, J.M. (1998). Die Lokus van Beheer-vraelys. Randse Afrikaanse Universiteit, Johannesburg.

Smith, C.A. Organ, D.W. \& Near, J.P. (1983). Organisational citizenship behavior: Its nature and antecedents. Journal of Applied Psychology, 68, 653-663

Tittle, C.K. (1982). Use of judgemental methods in item bias studies. In R.A. Berk (Ed.), Handbook of methods for detecting test bias. Baltimore: John Hopkins University Press.

Van Dyne, L. Cummings, L.L. \& McLean Parks, J. (1995). Extra role behaviors: In pursuit of construct and definitional clarity (a bridge over muddied waters) In L.L. Cummings \& B.M. Staw (Eds.), Research in organizational behaviour. Vol 17. Greenwich, CT: JAI Press.

Van Dyne, L., Graham, J. \& Dienesch, R.M. (1994) Organisational citizenship behaviour: Construct redefinition, measurement, \& validation. Academy of Management Journal, 37, 765-802.

Welch, J. (2001). Jack: What I've learned leading a great company and great people. London: Headline. 